\title{
Effects of Mobile Money on Beige Bank, Ghana
}

\author{
Emmanuel Acquah-Sam (PhD) \\ Dorothy Bugre
}

Wisconsin International University College, Legon, Accra, Ghana

Doi:10.19044/esj.2018.v14n31p29 URL:http://dx.doi.org/10.19044/esj.2018.v14n31p29

\begin{abstract}
The motivation for this study was that, existing literature have reported on the growth of mobile money (MM) and its clientele base. However, studies on the effects of mobile money service on customers and performance of an individual bank; challenges, threats, and opportunities mobile money service presents to an individual bank are very rare to find so adding to the existing studies on the sector will help provide more insight into the operations of the sector and direct policy decisions of policy-makers, bank officials, and telecom operators. This study sought to find out how mobile money services have affected customers and performance of Beige Bank in Ghana. The research is a descriptive survey design that presents results in mean scores, frequency distribution tables, pie charts, bar graph, and Chi-square test of relationship. The study found that mobile money service had a positive effect on customers' remittances. Also, mobile money positively influenced customers' saving habits. Furthermore, majority of the respondents had bank accounts, mobile money accounts, and still engaged in MM transactions. Again, instead of being a threat, mobile money presents opportunities like, cross selling of products, increase in customer base through the registration of mobile money agents, and increased bank commissionIt is recommended that Beige Bank, Ghana and other banks in Ghana should focus on getting mobile agents to save and buy E-cash from them, and develop mobile phone apps which provide access to mobile money service where customers can easily transfer money between their bank accounts and their mobile money wallets.
\end{abstract}

Keywords: Ghana, Beige Bank, Financial Inclusion, Demand for Money, Mobile Money, Descriptive Research Design

\subsection{BACKGROUND}

In spite of the focus access to finance has received in theory, empirical result that links broader access to financial services or financial inclusion to development outcomes has been very inadequate. Financial inclusion, or broad access to financial services, implies an absence of price and non-price barriers 
in the use of financial services. In this regard, financial services have to be available when and where they are desired, and products need to be tailored to specific needs of subscribers. Financial services need to be affordable. The extent to which households and small enterprises have direct access to financial services varies sharply around countries of the world, with very limited access in many developing countries (Demirgüç-Kunt, Beck, \& Honohan, 2008; Kodan \& Chhikara, 2013).

According to the Global Findex database 700 million adults worldwide became account holders between 2011 and 2014. The number of adults without an account - the unbanked - dropped by 20 percent to 2 billion. Globally, $62 \%$ of adults had an account, up from 51\% in 2011 (Demirguc-Kunt, Klapper, Singer, \& Oudheusden (2015).

The World Bank from its Universal Financial Access by 2020 (UFA, 2020) report states that as of $2014,59 \%$ of the 16.3 million adults in Ghana did not have bank transaction accounts (World Bank, 2015). The Universal Financial Access (UFA) by 2020 targets that, by 2020, adults worldwide should be able to access a transaction account or electronic instrument to store money, send and receive payments. Financial access is the initial step toward broader financial inclusion. In this, individuals and firms can safely use a range of appropriate financial services, such as savings, payments, credit and insurance. Lartey (2016) writes that though there is proliferation of financial institutions and substantial growth in the number of commercial and universal banks within Ghana, there still remains a large number of individuals who cannot qualify or meet the requirements to participate in the main stream banking system.

On the benefits of financial inclusion, Kodan \& Chhikara (2013) report that a $1 \%$ increase in the financial inclusion led to an average 0.142 per cent increase in the value of human development index. Being financially excluded means households and micro and small enterprises deal entirely in cash and are susceptible to irregular cash flows and burglary. Also, Baafi (2018) adds that financial inclusion occurs when individuals and businesses have access to useful, affordable financial products and services, and sustainable institutions that enable them meet their financial needs such as transactions, payments, savings, credit and insurance and are delivered in a more responsible and sustainable manner.

The Global Financial Database 2017, published by the World Bank, reported that, in 2017 over seven (7) million Ghanaians still remained outside the financial inclusion bracket despite the country's tremendous progress on the financial inclusion front. At the launch of the report in Ghana, Ms. Dorothe Singer, at the Finance and Private Sector Development Research Group of the World Bank, said globally, about 1.7 billion adult remain unbanked. That is, without an account at a financial institution or through a mobile money 
provider. In 2014, the number was two billion. Unfortunately, virtually all unbanked adults lived in developing economies. She pointed out that between 2014 and 2017, the share of adults who had an account with a financial institution or through mobile money services rose globally from $62 \%$ to $63 \%$. In developing economies, the share rose from $54 \%$ to $63 \%$. In Ghana, financial inclusion increased from 29\% in 2011 to $58 \%$ in 2018, largely driven by the adoption of digital financial services delivery in the country, particularly mobile money. In a bid to include more people in the financial sector, the Minister of Finance, Mr. Ken Ofori-Atta, in a speech read on his behalf, said the government had laid the foundation and set out the right measures and policies for the implementation of the financial inclusion strategy. He added that all the stakeholders within the echo system (the Bank of Ghana, the National Insurance Commission, the National Pensions Regulatory Authority, and the Securities and Exchange Commission), banks, telecommunication companies, and academia would be adequately sensitised to play their respective roles to ensure a comprehensive implementation of the strategy to increase the campaign on the outreach of financial services. In addition, the government was determined to harness the benefits of digitization by developing a national inclusive digital payment system as a first step towards the development of a digital economy (Bruce, 2018).

The introduction of mobile money service has been seen to helping solve some of the financial exclusion problems. From the urban centres to the remote villages in most parts of Sub-Sharan Africa, mobile money services can be accessed. People can now transfer and withdraw money even in communities which do not have formal financial institutions. For some people the formal banking system has certain disadvantages which hinder them from having bank transactions. Demirgüç-Kunt \& Klapper (2012) reveals that a total of $16 \%$ of adults in Sub-Saharan Africa used mobile money services to either pay bills, send or receive money.

An efficient payment system facilitates timely completion of financial transactions to enhance job creation, sustained economic growth, and improved standard of living amongst the citizenry of a country. The payment systems in Ghana include an array of institutional arrangements and processes such as Real Time Gross Settlement (RTGS), Cheque Codeline Clearing (CCC), Ghana Automated Clearing House (GACH) consisting of Direct Credit and Direct Debit, payments cards, E-zwich, Mobile Money (MM) and other payment service providers. The widespread proliferation of MM among the unbanked and underserved in recent years is underpinned by advances in handset functionality, chip and mobile network technologies, and upgrade in Point-Of-Sale (POS) infrastructure. MM services usage as a means of payment brings benefits to the user including convenience, speed, flexibility and affordability (GSMA, 2013; cited in Bank of Ghana, 2017) 
The BoG in its 2015 Annual Payment Systems Oversight Report reveal that, out of all the non-cash payment systems, mobile money services had the highest volume of transactions taking a mammoth share of $94.11 \%$ of non-cash payment systems. Mobile subscriptions growth in Ghana was $36.65 \%$ between 2012 and 2015 coupled with a $247.25 \%$ increase in cumulative registered mobile money customers. Complementing this quantum leap in the number of people who have registered for the mobile money service is the total transactions made through mobile money within these 3 years, with an increase in the total value of transaction from $\mathrm{GH} \phi 594.12$ million to $\mathrm{GH} \phi 35,444.38$. These figures in all indications show how fast MM has grown and how pivotal the mobile money service has become in Ghana's financial market, which has been made possible through the expansion of mobile telecommunication network coverage to remote villages where there exists no financial institution. The results of the Bank of Ghana (2017) study on the impact of mobile money on Ghana's Payment System suggests that improvement in the mobile money sub sector leads to development of the payment ecosystem, deepening of financial inclusion and promotion of cash-lite economy. Aidoo (2018) reports that "one significant initiative of the Bank of Ghana has been the opening up of the electronic money space to nonbanks and FinTech partnering banks. This has led to increased access to financial services and products for previously undeserved groups". The role of Mobile money services in Ghana's development and improvement in the lives of people continues to increase.

Data from the National Pension Regulatory Authority (NPRA) in 2018 had it that $85 \%$ of Ghana's labour force was in the informal sector, but the number of workers in the informal sector who had access to social benefits through institutionalised social security schemes was extremely low. It is to bridge this gap that exists between the formal and informal sector pension schemes that MTN Ghana in May, 2018 in collaboration with United Pension Trustees has introduced a flexible pension scheme dubbed "My Own Pension". The success of it lies in the fact that the rate of mobile phone penetration and mobile financial services provide the unique opportunity to secure the future of informal sector workers and Ghanaians in general (Kyeremeh, 2018).

Agyeman (2018) reports that, Dr. Mahamudu Bawumia, the VicePresident of Ghana, speaking at the launch of Ghana's first and only private inauguration of third party processing electronic payment company, PaySwitch Company Ltd, in Accra on Wednesday, May 9, 2018, said that the government of Ghana would soon stop accepting cash payments and instead encourage people to make electronic payments. Dr. Bawumia, hinted that a 2016 Bank of Ghana Report showed that the use of physical cash as the medium of exchange was on a continuous decline due to the increase in the use of other sources of payment, including cards, mobile money and the Ghana Interbank Payment and Settlement Systems (GhIPSS). In addition, 
Acheampong (2018) reports that the Ghana Investment Fund for Electronic Communications (GIFEC) is targeting a 95\% universal access to telephone services in rural communities by 2019. This is based on the successes made within the unserved and underserved communities in Ghana through its Rural Telephony Project (RTP). GIFEC intends to build the capacity of people, through education and awareness projects, to be able to use ICT in unserved and underserved communities to deliver services. For a start, one hundred and fifty (150) teachers have been trained as of June, 2018 and it is expected that one thousand five hundred $(1,500)$ school children will be trained by the end of first phase of the project.

The motivation for this study is that, existing literature report on the growth of mobile money and its clientele base. However, studies on the effects of mobile money service on customers and performance of an individual bank; challenges, threats, and opportunities mobile money service presents to an individual bank are very rare to find, because the sector is virtually new, and that adding to the existing studies on the sector will help provide more insight into the operations of the sector and direct policy decisions of policy-makers, bank officials, and telecom operators. The researchers chose Beige Bank in Ghana for this study, because since the Bank's establishment in 2008, until the recent Bank of Ghana's decision to consolidate Beige Bank, Construction Bank, Royal Bank, UniBank and Sovereign Bank into one single bank to become Consolidated Bank Ghana (CBG) Ltd, Beige Bank had maintained a consistent growth, making it one of the top brands in the banking industry in Ghana. As of the time this study was conducted, the number of branches operated by Beige Bank was seventy, and employed about two thousand $(2,000)$ staff, with over four hundred thousand $(400,000)$ customers. Further literature on the study is explored in Section 2.0.

\subsection{LITERATURE REVIEW}

Section 2.0 is a review of the theoretical models and empirical findings on financial inclusion, demand for money, and mobile money services and how it promotes financial development.

\subsection{Financial Inclusion}

In the work of Kodan \& Chhikara (2013), many researchers and thinkers are of the view that 'financial inclusion is the easy access of all people to the minimum basic financial services'. Ong-A-Kwie-Jurgens (2016) reports that the recent financial crisis in Suriname has brought to fore the need for international financial inclusion as it is believed that financial exclusion of a large segment of society was one of the factors that contributed to this crisis. Since many were excluded from the financial system, and that were not familiar with financial issues, fuelled the ignorance with regard to risks. 
Generally, the three segments of financial inclusion are access, depth and intermediation efficiency. Providing more information to borrowers, establishment of credit bureaus and registries to provide enough data in time regarding the borrowers and their credit worthiness will help assess the risk of default. Poor societies would be more impoverished continuously if the barriers for accessing financial services are not removed and the existing financial exclusion still hinder unbanked people to access financial institution (Demirgüc-Kunt et al. 2008; cited in Sidik, Achsani, \& Pasaribu, 2018). Efficient financial intermediation leads to improvement in total productivity and income growth. Financial inclusion increases a country's economic growth through decreasing income gap and poverty rate, and also to improve financial system stability. Sidik, Achsani, \& Pasaribu (2018) show that financial inclusion stimulates increases in demand for reserve money (M0) in developed countries, while it decreases the demand for reserve money (M0) in developing countries. MO is the sum of a country's currency in circulation and banks deposits.

\subsection{Theories of Demand for Money}

Among the prominent theories that have been advanced to explain the rationale for individuals holding money are: Fisher's Transactions Approach to Demand for Money, Cambridge Cash Balance Theory of Demand for Money, Keynes' Theory of Demand for Money, Tobin's Portfolio Approach to Demand for Money, and Friedman's Theory of Demand for Money (Mishkin (2015); Branson (1989).

Irvin Fisher's transactions approach to demand for money emphasised that money is demanded for the purposes of buying goods and services. Fisher explained his theory by the use of an equation: MV = PT. Where, $\mathrm{M}$ is the quantity of money in circulation (is exogenously determined by the central bank of a country and is assumed to be a given quantity in a particular period of time); $\mathrm{V}$ is transactions velocity of circulation which remains constant; $\mathrm{P}$ is Average price; $\mathrm{T}$ is the total number/volume of transactions (is also fixed in the short run). The number of transactions in a period is a function of national income and that the greater the national income, the larger the number of transactions required to be made and vice versa. The Cambridge Cash Balance Theory of Demand for Money developed by Alfred Marshall and A. C. Pigou also places emphasis on the function of money as a store of value or wealth. Money as a store of value holds that money is held as a general purchasing power by individuals over a period of time between the sale of a good or service and subsequent purchase of a good or service at a future date. Marshall and Pigou further opined that current interest rate, wealth owned by the individuals, expectations of future prices and future rate of interest were the main factors that determined individual's demand for holding cash balances, 
however, they believed that changes in these factors remain constant or they are proportional to changes in individuals' income. In conclusion, aggregate demand for money can be expressed as $\mathrm{M}_{\mathrm{d}}=\mathrm{kPY}$. Where, $\mathrm{Y}$ is real national income; $\mathrm{P}$ is average price level of currently produced goods and services; PY is nominal income; $\mathrm{k}$ is proportion of nominal income (PY) that people want to hold as cash balances.

Keynes' Theory of Demand for Money also known as liquidity preference theory suggests that an investor demands a higher interest rate, or premium, on securities with long-term maturities, because he/she carries higher risk. Investors, however, prefer cash or other highly liquid assets, owing that investments that are more liquid are easier to sell fast for full value. A person's desire for liquidity or cash holding are for transactions purposes, precautionary purses, and speculative purposes. Total demand for money is represented by $\mathrm{M}_{\mathrm{d}}$. The part of $\mathrm{M}$ held for transactions and precautionary motive is denoted by $\mathrm{M}_{1}$ and that part held for the speculative motive as $\mathbf{M}_{2}$. Thus $\mathrm{M}_{\mathrm{d}}=\mathrm{M}_{1}+\mathrm{M}_{2}$. Also, James Tobin explained that rational behaviour on the part of the individuals is that they should keep a portfolio of assets which consists of both bonds and money. He assumed that people prefer more wealth to less. However, according to him, an investor is faced with a problem of what proportion of his portfolio of financial assets he/she should keep in the form of money and interest-bearing bonds. Individuals diversify their portfolio by holding a balanced combination of safe and risky assets. Hence, an individual's behaviour shows risk aversion. Tobin derived his liquidity preference function by arguing that with the increase in the rate of interest, wealth holders will be generally attracted to hold a greater fraction of their wealth in bonds and thus reduce their holding of money.

Baumol concentrated on transactions demand for money and explained it from the viewpoint of inventory control or inventory management similar to the inventory management of goods and materials by business firms. Baumol asserts that individuals hold inventory of money because this facilitates transactions of goods and services. Just as businesses incur cost on holding inventories of goods and as a result keep optimal inventory of goods to reduce cost, so individuals have to keep optimum inventory of money for transactions purposes so as to reduce the cost of holding inventories of money for transaction purposes. The cost they incur on these inventories is the interest they forgo which they could have earned if they had kept their wealth in saving deposits or fixed deposits or invested in bonds. In this case both Baumol and Tobin explain that transaction demand for money is dependent upon the rate of interest.

Friedman holds the view that individuals like other capital assets; money also yields return and provides services. The real yield of money, he defined in terms of goods and services which it can purchased, which also 
depends on the price level of goods and services. Friedman's nominal demand for money function $\left(\mathrm{M}_{\mathrm{d}}\right)$ can be written as: $\mathrm{M}_{\mathrm{d}}=\mathrm{f}\left(\mathrm{W}, \mathrm{h}, \mathrm{r}_{\mathrm{m}}, \mathrm{r} \mathrm{b}, \mathrm{re}, \mathrm{P}, \Delta \mathrm{P} / \mathrm{P}, \mathrm{U}\right)$. Where; $\mathrm{M}_{\mathrm{d}}$ is nominal demand for money; $\mathrm{M}_{\mathrm{d}} / \mathrm{P}$ is demand for real money balances; $\mathrm{W}=$ wealth of the individuals; $\mathrm{h}$ is proportion of human wealth to the total wealth held by the individuals; $r_{m}$ is rate of return or interest on money; $\mathrm{r}_{\mathrm{b}}$ is rate of interest on bonds; $\mathrm{r}_{\mathrm{e}}$ is rate of return on equities; $\mathrm{P}$ is the price level; $\Delta \mathrm{P} / \mathrm{P}$ is the change in price level (i.e. rate of inflation), and $\mathrm{U}$ is the institutional factors. If we assume that no price change is anticipated and institutional factors such as $\mathrm{h}$ and $\mathrm{U}$ remain fixed in the short run and also all the three rates of interest return are clubbed into one, Friedman's demand for money function is simplified to $\mathrm{M}_{\mathrm{d}}=\mathrm{f}\left(\mathrm{Y}_{\mathrm{pr}}\right)$.

\subsection{Mobile Money Services}

Global System for Mobile Communications Association (GSMA), an international body that represents mobile operator's worldwide, refers to mobile money as the use of the mobile phone to transfer money and make payments. According to GSMA the following are the requirements for a service to be considered as a mobile money service:

- Mobile payments should include bill payment, bulk disbursement, and merchant payment, domestic or international transfer.

- A mobile money service must rely mainly on a network of transactional points outside bank branches and ATMs. That makes the service accessible to unbanked and under banked people.

- Customers must be able to use the service even if they do not have previous banking experience.

In the words of Jack \& Suri (2011), consumer-level technology history has not witnessed the growth of anything as fast as the growth rate of mobile phones. Mobile money services thrive on the availability of mobile phones and mobile network coverage. Infrastructure for physical transportation in SubSaharan Africa has often been inadequate, unreliable, and deplorable .This had initially made cost of communication very expensive, but mobile phone technology has come to the rescue, reducing the cost drastically (Jack \& Suri, 2011). The advantages of mobile phone financial transactions are that, they are safer, time saving, and has the ability to reach more customers in the shortest possible time (Bangens \& Soderberg, 2008; Ngaruiya, Bosire, \& Kamau, 2014; Haggins, Kendall, \& Lyon, 2012; Jensen, 2007), this has helped people to conduct multiple transactions.

\subsubsection{Mobile Money Service in Ghana}

In Ghana MM service was first introduced into the financial system in 2009 by MTN. Now there are three additional mobile money services providers (Tigo, Airtel, and Vodafone). Ghana's success story is owed to the 
spread of mobile network providers in the country, the role of the Government of Ghana, and BoG in providing appropriate regulations and infrastructure. The National Communication Authority (NCA) in their June quarterly statistical report on communications in Ghana indicated 36.6 million mobile subscriptions as of June 2016, with a mobile penetration rate of $131.9 \%$ (NCA, 2016). Along this increase in mobile subscription is the increase in the cumulative registered mobile money customers in the country. The BoG's Third Quarter 2016 Payment System Statistics show that between the months of September 2015 to the following year 2016, the number of registered mobile money customers increased by an additional 7,901,935 people. The number of active customers also more than doubled with a growth rate of $104.12 \%$, the volume and value of transactions also more than doubled with growth rates of $102.31 \%$ and $115.83 \%$, respectively (BoG, 2016). As of 2015, the Consultative Group to Assist the Poor (CGAP) estimated that $20 \%$ of Ghanaian adults had mobile money accounts. The group went on to tip Ghana as the most ready country in Africa to move into full digital financial service (DFS) provision based on the facts that $92 \%$ of Ghanaian adults have the required ID to open an account, 95\% have basic numeracy and 91\% own mobile phones (CGAP, 2015a). Price Water House Coopers (PWC, 2016). Ghana Banking Survey on the impact of mobile money service on banks' operations, report that, $29 \%$ believed mobile money services had heavy impacts on the operations of banks, while $57 \%$ said the impact was moderate, and 14\% classifying the impact as very little.

\subsection{Opportunities and Challenges of Mobile Money Service for Formal Financial Institutions}

Mobile money provides both an opportunity and a challenge to financial institutions (Muisyo, Alala, \& Musiega, 2014; and PWC, 2016). The 2016 Ghana Bank Survey reported that although all bankers agree mobile money presents opportunities, $71.4 \%$ believed there existed threats and opportunities. When further asked to rate how much an opportunity mobile money is, $33.3 \%$ rated it at 5 (very high) and also $33.3 \%$ rated it at 4 (high), showing that majority agreed that mobile money services presented opportunities. With the question of mobile money being a threat, 55.6\% rated it at 3 emphasising the fact that although there existed threats there were still opportunities. Most of the challenges mobile money poses to financial institutions, if properly addressed can become opportunities. Formal financial institutions need to stop looking at mobile money as a competitor, but rather as a means to expand. The PWC (2016) and Muisyo, Alala, \& Musiega (2014), both advice that financial institutions should note that mobile money is an imperative route for consumer banking and has the benefit of providing massive and cheap deposits for them if they could position themselves well. 
GSMA also stress on the fact that although mobile money services are increasingly becoming pivotal in the financial sector, majority of the services accessed are limited to $\mathrm{P} 2 \mathrm{P}$ transfers. There are great opportunities in bulk disbursements, with B2P transfers, D2P transfers and G2P transfers, having the potential to serve many customers with a single transaction. There is the need for a regulatory body that will ensure a balance in both industries by issuing appropriate legislations that will ensure they work together (GSMA, 2015).

Section 3.0 provides the methods adopted to address the research gap, and objectives of the study.

\subsection{METHODOLOGY}

This section presents the research design, sampled population of the study, sampling technique, the data collection instruments, ethical considerations, reliability test, and tools of data analysis and presentations employed. Quantitative and qualitative approaches were used. The mixed approach was to make the findings easy to be understood by prospective readers, and stakeholders in the banking and telecom industries. The qualitative approach used an interview guide to discuss important issues with top officials of Beige Bank. The quantitative approach centred on data obtained from close-ended questionnaires that were administered to some selected customers and bank officials. The study is underpinned by theories of demand for money as explained in Section 2.2.

\subsection{Population, Sampling Techniques, Data Type, and Reliability of the Data Collection Instruments}

The population is made up of the customers and staff of Beige Bank, Ghana. A sample of One hundred (100) was used in conducting the study. This was made up of seventy (70) customers and thirty (30) bank officials. The researchers administered questionnaires to the staff of Beige Bank working as customer service, audit officers, branch support officers, administrative assistants, HR officers, Field banking supervisors, remittance officers, operations officers, operations team leads, and clearing officers. The interview guide and questionnaires were personally administered by the researchers. Seven branches were used in the study. These branches included the Kwabenya Branch, Adenta Branch, Madina Market Branch, Madina Zongo-Junction Branch, Accra UTC Branch, Haatso Branch, and Kokomlemle Branch. The researchers used purposive sampling (judgemental or subjective sampling) technique to identify relevant customers and employees in key departments of Beige Bank Specifically, the researcher used convenience sampling technique in selecting customers of Beige Bank who responded to the questionnaires. An introductory letter was sent to the Management of the Beige Bank to formally 
seek permission to talk to customers and employees who were relevant to the study. The study conducted a reliability analysis based on the suggestion of Polit \& Hungler (1999). The results of the reliability test are presented in Table 3.1 .

Table 3.1 Test of Reliability Analysis

\begin{tabular}{ccccc}
\hline Dimensions of Scale & $\begin{array}{c}\text { Cronbach } \\
\text { 's Alpha }\end{array}$ & $\begin{array}{c}\text { Cronbach's Alpha Based on } \\
\text { Standardized Items }\end{array}$ & $\begin{array}{c}\text { N of } \\
\text { Items }\end{array}$ & No of Valid Cases \\
\hline Bank Officials(Scale) & .730 & .779 & 20 & $70 * 96.7 \%$ \\
Customers (Scale) & .716 & .745 & 39 & $70 * 78.6 \%$ \\
\hline
\end{tabular}

The confidence level of the analysis was pegged at $95 \%$ (0.05) level of significance. The scale has two dimensions - bank officials and customers of banks. The results show high Cronbach Alpha values for both dimensions.

\subsection{Tools of Data Analysis and Presentation}

In analysing data collected, Statistical Package for Social Sciences (SPSS) and Microsoft Excel were used. Also, descriptive statistics tools used included mean scores, standard deviations, percentages, frequency distribution tables, pie charts, bar charts and Chi-square test. The recorded interviews were transcribed and content analysis was used to analyse the data that were obtained.

\subsection{RESULTS AND DISCUSSIONS}

This section presents the results from the data obtained from sampled respondents. The results are organised into Section A and Section B. Section A covers the analysis of data obtained from the Bank's customers and Section B covers the analysis of data obtained from the Bank's officials.

\subsection{Section A: Customers}

This section analyses the data collected from the 70 customers of Beige Bank

\subsubsection{Demographic Characteristics of Customers}

The characteristics of customers as shown in Table 4.1include: Ages, gender, educational level, marital status, and employment. 
Table 4.1 Demographic Characteristic of Customers

\begin{tabular}{|c|c|c|c|}
\hline Demographic Information & Categories & Frequency & Percent (\%) \\
\hline \multirow[t]{3}{*}{ Gender } & Male & 36 & 51.4 \\
\hline & Female & 34 & 48.6 \\
\hline & Sub-Total & 70 & 100 \\
\hline \multirow[t]{5}{*}{ Age } & 18-24 years & 5 & 7.14 \\
\hline & 25-34 years & 51 & 72.86 \\
\hline & $35-44$ yeas & 12 & 17.14 \\
\hline & 60 or Over & 2 & 2.86 \\
\hline & Sub-Total & 70 & 100 \\
\hline \multirow[t]{6}{*}{ Educational Level } & Primary & 2 & 2.86 \\
\hline & Secondary/High School & 11 & 15.71 \\
\hline & Diploma & 2 & 2.86 \\
\hline & Degree & 49 & 70.0 \\
\hline & Masters & 6 & 8.57 \\
\hline & Sub-Total & 70 & 100.0 \\
\hline \multirow[t]{5}{*}{ Marital Status } & Married & 26 & 37.14 \\
\hline & Divorced/ Separated & 1 & 1.43 \\
\hline & Single/Never Married & 42 & 60.0 \\
\hline & Widowed & 1 & 1.43 \\
\hline & Sub-Total & 70 & 100.0 \\
\hline \multirow[t]{5}{*}{ Employment Level } & Employed & 61 & 87.14 \\
\hline & Not employed & 1 & 1.43 \\
\hline & Self employed & 7 & 10.0 \\
\hline & Missing value & 1 & 1.43 \\
\hline & Sub-Total & 70 & 100.0 \\
\hline
\end{tabular}

Source: Field Data, 2017

As indicated in Table 4.1, information on gender was captured to help examine the level of participation of male and female customers who do business with Beige Bank. The results show that majority of the respondents were males (representing 51.4\%) and $48.6 \%$ were females. The results further indicate that majority of the respondents were within 25-34 years bracket, representing $72.86 \%$ of the respondents, followed by $35-44$ years bracket, representing $17.14 \%$, whiles 60 years and above represented $2.86 \%$ of the respondents. The implication of the large number of young people forming the bulk of the respondents is that the implementation of MM services has a bright future because of their understanding of the use of mobile phone apps. Also, the educational levels of respondents show that majority had first degree, representing $70 \%$, followed by secondary/high school certificates, master's degree and those with primary and diploma certificates representing $15.71 \%$, $8.57 \%$ and $2.86 \%$ respectively.

In addition, the results indicate that majority of respondents are single, representing $60 \%$, this is followed by those married, who represents $37.14 \%$, and the least represents divorced/separated and widowed, this represents $1.43 \%$ of respondents. Furthermore, the results show that almost all 
respondents were employed, representing $87.14 \%$, whiles minimal numbers are self-employed, and unemployed representing $10.0 \%$ and $1.43 \%$ respectively. The overall statistics imply that respondents had the requisite backgrounds to understand and provide appropriate responses to the questions asked by the researchers.

\subsubsection{Use of Mobile Money Services}

Table 4.2 presents the results of respondents (customers) responses to the question regarding mobile money services and bank account operations.

Table 4.2 Use of Mobile Money Services

\begin{tabular}{|c|c|c|c|c|c|c|}
\hline \multirow[t]{2}{*}{$\begin{array}{c}\text { Statements or Indicators } \\
\text { Customers }\end{array}$} & \multicolumn{2}{|c|}{ YES } & \multicolumn{2}{|c|}{ NO } & \multirow[t]{2}{*}{$\begin{array}{l}\text { Missing } \\
\text { Value } \\
\end{array}$} & \multirow[t]{2}{*}{ SD } \\
\hline & Freq. & $\%$ & Freq. & $\%$ & & \\
\hline Do you use mobile money services? & 66 & 94.3 & 2 & 2.9 & 2 & .17 \\
\hline Do you have a mobile money account? & 57 & 81.4 & 11 & 15.7 & 2 & .37 \\
\hline Do you have a bank account? & 70 & 100.0 & - & - & - & .00 \\
\hline & \multicolumn{2}{|c|}{ Bank Account } & \multicolumn{2}{|c|}{ Mobile Account } & & \\
\hline $\begin{array}{l}\text { Comparing your bank account to your } \\
\text { mobile account, which one do you } \\
\text { frequently use? (Q9) }\end{array}$ & 35 & 50.0 & 32 & 45.7 & 3 & .50 \\
\hline $\begin{array}{l}\text { Why did you choose the answer above? } \\
\text { (Q9) }\end{array}$ & \multicolumn{2}{|c|}{ YES } & \multicolumn{2}{|c|}{ NO } & & \\
\hline Closer & 30 & 42.9 & 40 & 57.1 & - & .50 \\
\hline Cheaper & 11 & 15.7 & 59 & 84.3 & - & .37 \\
\hline Faster & 32 & 45.7 & 38 & 54.3 & - & .50 \\
\hline No need to fill forms & 8 & 11.4 & 62 & 88.6 & - & .32 \\
\hline
\end{tabular}

Source: Field Data, 2017

The results in Table 4.2 illustrate respondents (customers) use of mobile money in Beige Bank. SD stands for standard deviation. Out of the 70 sampled customers, $94.3 \%$ used mobile money services, whiles $2.9 \%$ admitted not using the services, and 2 were missing values. In addition, $81.4 \%$ of the respondents had mobile money accounts, whiles $15.7 \%$ did not have. However, the entire sampled respondents $(100.0 \%)$ admitted they had bank accounts. The results show that $50 \%$ of respondents answered they used bank accounts frequently, whiles $45.7 \%$ used mobile money account frequently. However, there were 2 missing values. The findings suggests that majority of Beige Bank customers used mobile money service and mobile money accounts making it easier for the mobile money concept to be incorporated into the financial Bank's system and into Ghana's financial system. These finding help address the problem reported by the World Bank about the gap in bank accounts holdings of adults in Ghana as at 2014 (World Bank, 2014). 


\subsubsection{Effects of Mobile Money Services on Respondents' Remittances}

The study examined the effect of mobile money service on respondents' remittances. The results from the descriptive statistics and Chisquare analysis are shown in Tables 4.3 4.4 and 4.5. In Table 4.3, we read that out of the seventy sampled customers of the Bank, majority used mobile money service through the Bank. This formed $62.9 \%$ of the respondents. Whiles $37.1 \%$ did not utilise the service through the bank.

The analyses further indicate that a greater number of respondents, forming $61.4 \%$ preferred accessing mobile money service through agents, whiles those who accessed mobile money service through the Bank constituted only $38.6 \%$. Furthermore, in Table 4.3, the analysis of the question of the use of other money transfer products, the results indicate that significant majority of the sample that represents $75.7 \%$, did not use any other money transfer product besides mobile money. However, a minority of the sample that represents $22.9 \%$ admitted to have used other money transfer services provided by the Bank. About those who said yes to using other money transfer services besides the mobile money, the results show that majority used B-Cash, followed by Wari, these represent $10.0 \%$ and $1.4 \%$. These findings suggest that mobile money service is actually fulfilling the reasons for which it was introduced as stated by Ngaruiya, Bosire, \& Kamau, (2014). In order to examine the real effects of mobile money services on remittance service of Beige Capital, the study conducted a chi-square test. The results are shown in Table 4.4 and Table 4.5.

Table 4.3 Descriptive Statistics on Use of Remittance Service

\begin{tabular}{|c|c|c|c|c|c|c|c|}
\hline \multirow[t]{2}{*}{$\begin{array}{c}\text { Statements or Indicators } \\
\text { Customers } \\
\end{array}$} & \multicolumn{2}{|c|}{ YES } & \multicolumn{2}{|c|}{ NO } & \multirow[t]{2}{*}{$\begin{array}{l}\text { Missin } \\
\text { g Value }\end{array}$} & \multirow[t]{2}{*}{$\begin{array}{l}\text { Mea } \\
\text { n }\end{array}$} & \multirow[t]{2}{*}{ SD } \\
\hline & Freq. & $\%$ & Freq. & $\%$ & & & \\
\hline $\begin{array}{l}\text { Have you ever used mobile money } \\
\text { service through the bank? }\end{array}$ & 44 & 62.9 & 26 & 37.1 & - & 1.37 & .48 \\
\hline $\begin{array}{l}\text { Do you prefer accessing mobile } \\
\text { money through the bank or agents? } \\
\text { (Q12) }\end{array}$ & $\begin{array}{l}\text { Banks } \\
27\end{array}$ & 38.6 & $\begin{array}{l}\text { Agents } \\
43\end{array}$ & 61.4 & - & 1.61 & .49 \\
\hline $\begin{array}{l}\text { Apart from mobile money, do you use } \\
\text { any other money transfer service } \\
\text { offered by the bank? (a) }\end{array}$ & 16 & 22.9 & 53 & 75.7 & 1 & 1.77 & .42 \\
\hline \multicolumn{8}{|l|}{ If yes, please circle all that apply (b) } \\
\hline Wari & 1 & 1.4 & 69 & 98.6 & - & .01 & .12 \\
\hline B-Cash & 7 & 10.0 & 63 & 90.0 & - & .10 & .30 \\
\hline \multicolumn{8}{|c|}{$\begin{array}{c}\text { Source: Field Data, } 2017 \\
\text { Table 4.4 Descriptive Statistics from Chi-square Result }\end{array}$} \\
\hline Variables & Mean & Std. I & viation & Minimum & & Maximı & \\
\hline Mobile Money Service & 3.1912 & & & 3.00 & & 5.00 & \\
\hline Remittance Service & 4.7536 & & & 3.00 & & 6.00 & \\
\hline
\end{tabular}

Source: Field Data, 2017 
The descriptive statistics in Table 4.4, regarding the relationship between mobile money service and remittance service, shows that remittance service obtained the greatest mean value of 4.75 as against 3.19 by mobile money service. The $\mathrm{N}$ value was pegged at 69 , SD values of .47 for mobile money and .93 for remittance service. The established relationship between the two variables is shown in Table 4.5.

The Chi-square results in Table 4.5 with regards to mobile money service and remittance service shows that the two variables are positively related based on alpha level of $0.05(95 \%)$. This is indicated by mobile money service $[\chi=79.088, \mathrm{df}=2$, Asymp. Sig. $=.000, \mathrm{p}<0.05]$ and remittance service $[\chi=79.088, \mathrm{df}=2$, Asymp. Sig. $=.000, \mathrm{p}<0.05]$. It will be important for the Bank to intensify its educational campaign and marketing drive to get more customers and encourage them to use the Bank for their MM and transactions.

Table 4.5 Chi-Square Test Statistics

\begin{tabular}{ccc}
\hline Indicators & Mobile Money Service & Remittance Service \\
\hline Chi-Square $(\chi)$ & $79.088^{\mathrm{a}}$ & $11.870^{\mathrm{b}}$ \\
Df & 2 & 3 \\
Asymp. Sig. & .000 & .008 \\
\hline
\end{tabular}

[a. 0 cells (.0\%) have expected frequencies less than 5. The minimum expected cell frequency is 22.7. b. 0 cells (.0\%) have expected frequencies less than 5. The minimum expected cell frequency is 17.3.]

\subsubsection{Average Money Sent through Mobile Money}

Furthermore, the study investigated the amount of money respondents on the average sent on monthly basis through mobile money. The results show

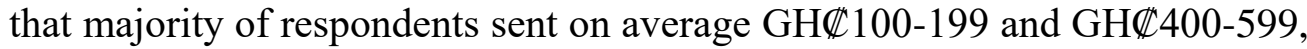
representing $26.0 \%$, followed by $20.0 \%$ who sent $\mathrm{GH} \not 200-399$. Next to these were those who sent on average less than GH $\not 100$ (representing $11.15 \%$ ), and the least represented were those who sent on average GH\&600-799, representing 2.3\%. The results are presented in Figure 4.1.

\section{Average Money Sent through MM (GHC)}

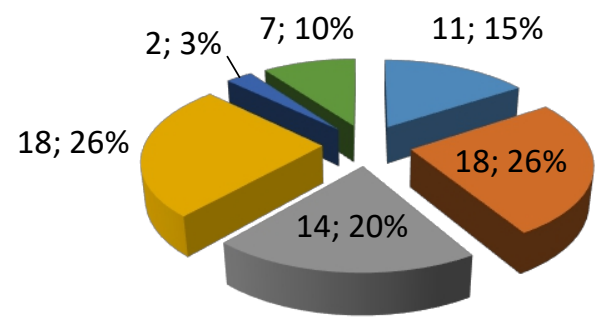

$$
\begin{aligned}
& \text { Less than } 100 \\
& \text { 100-199 } \\
& 200-399 \\
& 400-599 \\
& 600-799
\end{aligned}
$$

Figure 4.1: Average Amount of Money Sent Through Mobile Money by Customers Source: Field Data, 2017 


\subsubsection{Effect of Mobile Money Service on the Saving Attitude of Customers of Beige Bank}

The researchers wanted to find out if customers preferred to save using mobile money. The results are presented in Table 4.6. Thirty percent (30\%) majority of the sampled respondents agreed with the statement, $14.3 \%$ strongly agreed to the statement, whiles $27.1 \%$ disagreed. The least number of $11.4 \%$ were those who strongly disagreed with the statement, and $15.7 \%$ stayed neutral. The implication of majority of respondents agreeing to save using MM is that the nation can use MM as an avenue to promote the culture of saving amongst Ghanaians to mobilise savings for investment projects. Beige Bank must also device means of using MM to attract customers to save with the Bank.

In Table 4.6 respondents responded to the statement "I have increased my saving on mobile money". The results show that a significant number of sampled respondents, representing $37.1 \%$, disagreed with the statement, while $21.1 \%$ were uncertain. Those who strongly agreed formed $7.1 \%$. Again, the results show that a number of respondents, although minimal, representing $15.7 \%$ ticked agree to the statement. $11.4 \%$ ticked strongly disagree to the statement. The general impression here is that many do not add to their MM wallet may be due to inadequate income flows. Furthermore, on the statement "Mobile money has changed my saving habit", the results show that a significant majority of sampled respondents ticked agree, representing 32.9\%, and is followed by those who ticked disagree, representing $28.6 \%$. Those who chose uncertain formed $18.6 \%$ of the respondents, and those who ticked strongly agree formed $5.7 \%$ of the respondents. The last group is made up of those who ticked strongly disagree, representing $12.9 \%$. The conclusion is that MM has not changed the saving habits of respondents. A lot more of education is needed to inform customers about the benefits of saving with the Bank through MM.

Table 4.6 Effect of Mobile Money on Saving Attitudes of Customers

\begin{tabular}{|c|c|c|c|c|c|c|c|c|c|c|}
\hline \multirow[t]{3}{*}{ Statements } & \multicolumn{10}{|c|}{ Scale } \\
\hline & \multicolumn{2}{|c|}{$\mathbf{S A}$} & \multicolumn{2}{|c|}{$\mathbf{A}$} & \multicolumn{2}{|c|}{$\mathbf{U N}$} & \multicolumn{2}{|c|}{$\mathbf{D}$} & \multicolumn{2}{|c|}{ SD } \\
\hline & Frq. & $\%$ & Frq. & $\%$ & Frq. & $\%$ & Frq. & $\%$ & Frq. & $\%$ \\
\hline I prefer to save using mobile money. & 10 & 14.3 & 21 & 30.0 & 11 & 15.7 & 19 & 27.1 & 8 & 11.4 \\
\hline $\begin{array}{l}\text { I have increased my saving on mobile } \\
\text { money }\end{array}$ & 5 & 7.1 & 11 & 15.7 & 19 & 27.1 & 26 & 37.1 & 8 & 11.4 \\
\hline $\begin{array}{c}\text { Mobile money has changed my } \\
\text { saving habit }\end{array}$ & 4 & 5.7 & 23 & 32.9 & 13 & 18.6 & 20 & 28.6 & 9 & 12.9 \\
\hline $\begin{array}{l}\text { Mobile money agents are closer to } \\
\text { me than the bank }\end{array}$ & 29 & 41.4 & 28 & 40.0 & 4 & 5.7 & 7 & 10.0 & 1 & 1.4 \\
\hline $\begin{array}{l}\text { Majority of my money transfers are } \\
\text { through mobile money. }\end{array}$ & 22 & 31.4 & 22 & 31.4 & 9 & 12.9 & 13 & 18.6 & 3 & 4.3 \\
\hline $\begin{array}{l}\text { Sending money through mobile } \\
\text { money is cheaper than other money } \\
\text { transfer service offered by the bank }\end{array}$ & 15 & 21.4 & 17 & 24.3 & 19 & 27.1 & 11 & 15.7 & 7 & 10.0 \\
\hline
\end{tabular}


Source: Field Data, 2017

(SA-strongly agree, A-agree, Un-uncertain/neutral, D-disagree and SD- strongly disagree)

Moreover, on the statement "Mobile money agents are closer to me than the bank" the result indicates that a greater number of respondents ticked strongly agree, representing $41.0 \%$, followed by those who ticked agree, representing $40.0 \%, 5.7 \%$ were uncertain, $10 \%$ ticked disagree, and the least represented are those who ticked strongly disagree, representing $1.4 \%$. The results generally show that respondents were comfortable with mobile agents because of their closeness and that did they did have little dealings with bank accounts or the Bank. . The implication is that the Bank must register mobile money agents so that their wallet will be hooked with their Bank accounts to indirectly get access to customers who use MM.

In addition, the results show that on the indication of "Majority of my money transfer is through mobile money" majority ticked strongly agree, representing $31.4 \%$ as well as agree, representing $31.4 \%$ and the lowest representation are those who ticked strongly disagree, representing $4.3 \%$. This implies that Ghanaians have come to terms with the use of MM helping to promote financial inclusion.

On the issue of "Sending money through mobile money is cheaper than other money transfer service offered by the bank", majority of the sampled respondents ticked uncertain, representing $27.1 \%$. This was followed by those who ticked agree, representing $24.3 \%$, those who ticked strongly agree formed $21.4 \%$, the disagreed formed $15.7 \%$, and the least represented those who ticked strongly disagree, constituting $10.0 \%$. On the whole, the implication is that other factors other than the cheapness of the use of the service accounted for the use of MM by respondents. The Bank must explore these factors and use them to its advantage. Lastly, on the issue of "Sending money through mobile money is faster", a $48.6 \%$ of the sampled respondents ticked agree, $12.9 \%$ also ticked strongly agree, whilst $11.4 \%$ ticked uncertain, $4.3 \%$ ticked disagree, and the least $1.4 \%$ ticked strongly disagrees. The fastness of MM service has influenced the saving attitude of respondents. The implication here is that even if the Bank ties agents and customers wallets to their bank accounts and still does not expedite action on customers' needs or services at the bank, they may likely stay away from the Bank.

In order to examine the real effects of mobile money services on savings attitudes of customers, a chi-square test was conducted and the result is shown in Table 4.7. The results show that the two variables are positively correlated at a significant level of $0.05(95 \%)$. This is indicated by mobile 
money service $[\chi=79.088, d f=2$, Asymp. Sig. $=.000, p<0.05]$ and remittance service $[\chi=34.174, d f=2$, Asymp. Sig. $=.025, p<0.05]$.

Table 4.7 Chi-Square Test Statistics on Mobile Money Service and Savings Attitudes of Customers

\begin{tabular}{ccc}
\hline Indicators & Mobile Money Service & Savings Attitudes of Customers \\
\hline Chi-Square & $79.088^{\mathrm{a}}$ & $34.174^{\mathrm{b}}$ \\
Df & 2 & 20 \\
Asymp. Sig. & .000 & .025 \\
\hline
\end{tabular}

[a. 0 cells (.0\%) have expected frequencies less than 5. The minimum expected cell frequency is 22.7.

b. 21 cells (100.0\%) have expected frequencies less than 5. The minimum expected cell frequency is 3.3.

The results in Table 4.7 clearly show that mobile money service exerts a moderate significant effect on saving attitudes of customers in Beige Bank. On the effects of mobile money on savings, one of the interviewed senior officials added that; "They save money on their wallet and that is why the regulator says they should pay interest on that, but if you are a bank and you can pay more, you can now entice them to move money from their wallet to their bank accounts, so you give them that service where they move their money from their wallet to their bank accounts. Telco's do not give loans, they cannot trade with the money, so it is the banks that give them the profit and they go and share it with the customers, so if you are a customer, it means that you are sharing part of your profit. But, if I make you aware that you can take all the money you are sharing with the Telcos, why not?"

Mobile money service exerts moderate effects on the savings pattern of customers of Beige Bank and that implies that customers should have much preference for bank services. This implies that customers must be educated on the uses of mobile money services.

\subsubsection{Amount of Money Customers Saved Through Mobile Money}

In addition, the study investigated the amount of money customers saved through mobile money on a monthly basis. The results are presented in Figure 4.2. The results on monthly mobile money savings by customers as shown in Figure 4.2 reveal that majority (21.4\%) saved less than $\mathrm{GH} \mathbb{C} 100$ a month, those who saved between GHC100-199 (15.7\%). Next, about 14.3\% saved between $\mathrm{GH} \mathscr{2 0 0 - 3 9 9}$, and the least $1.4 \%$ were those who saved GHC 1,000 and more. However, a significant number of respondents forming, $38.6 \%$, did not respond to this question. The implication is that the proper management of MM system will promote savings mobilisation in Ghana for national development with increased incomes of customers. 


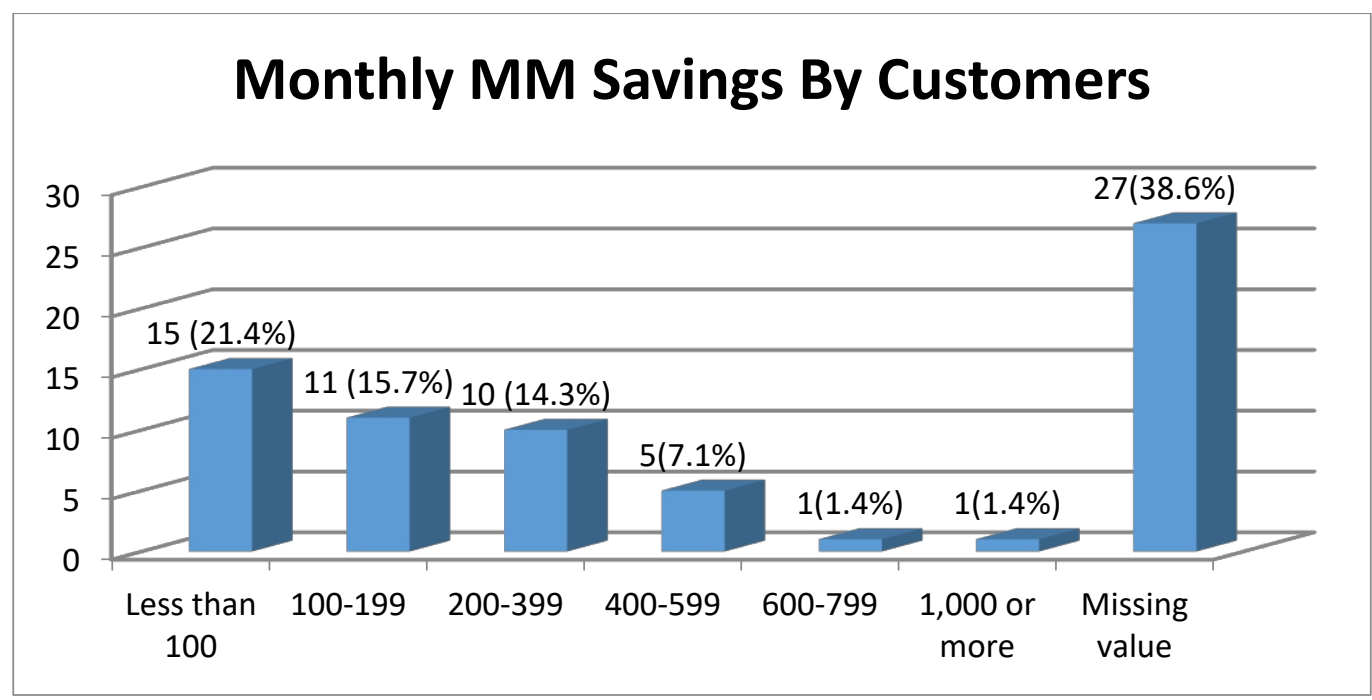

Figure 4.2 Monthly Mobile Money Savings by Customers (Amount in Ghana Cedi) Source: Field Data, 2017

\subsubsection{Amount of Money Customers Save in their Bank Accounts Monthly}

In Figure 4.3, the study also explored how much customers saved in their bank accounts monthly. The results indicate that a greater number of sampled respondents saved between GH $200-399$ in their bank accounts, representing $30.0 \%$ of the respondents. It is followed by $15.7 \%$ who saved

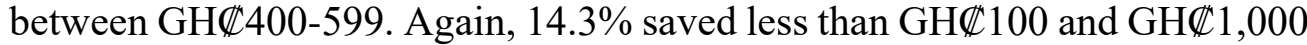
and more. The remaining 5.7\% saved between GH\&800-999.

\section{Monthly Bank Account Savings by Customers}

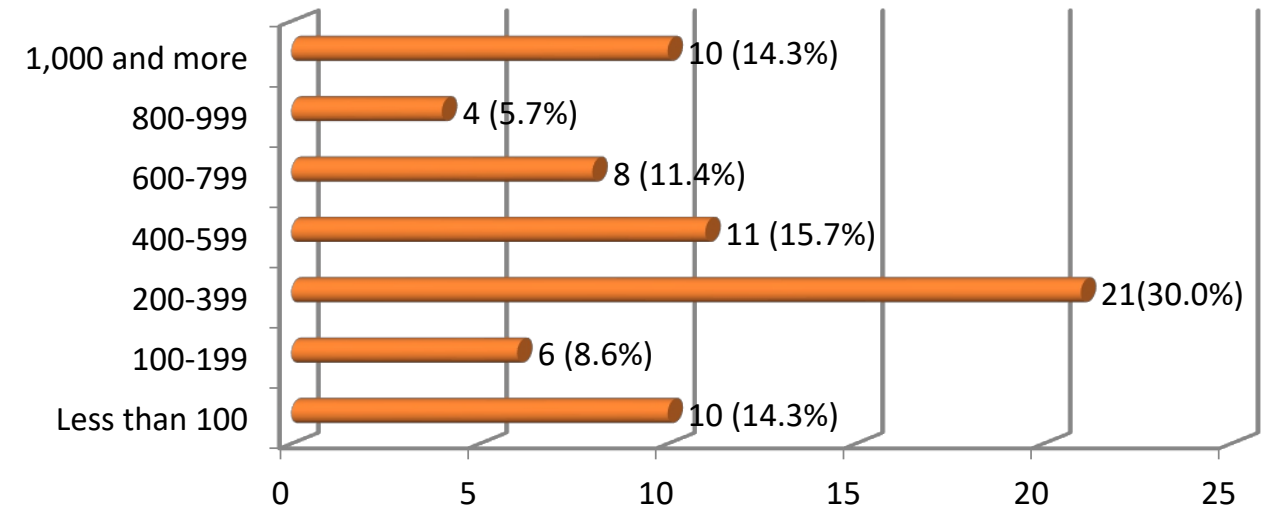

Figure 4.3 Bank Account Savings by Customers in a Month (Amount in Ghana Cedi) Source: Field Data, 2017 


\subsubsection{Improving Mobile Money Services}

The study also sought from customers what could be done to improve the mobile money system. The results are shown in Figure 4.4.

\section{What Should be Done to Improve MM Transfer System}

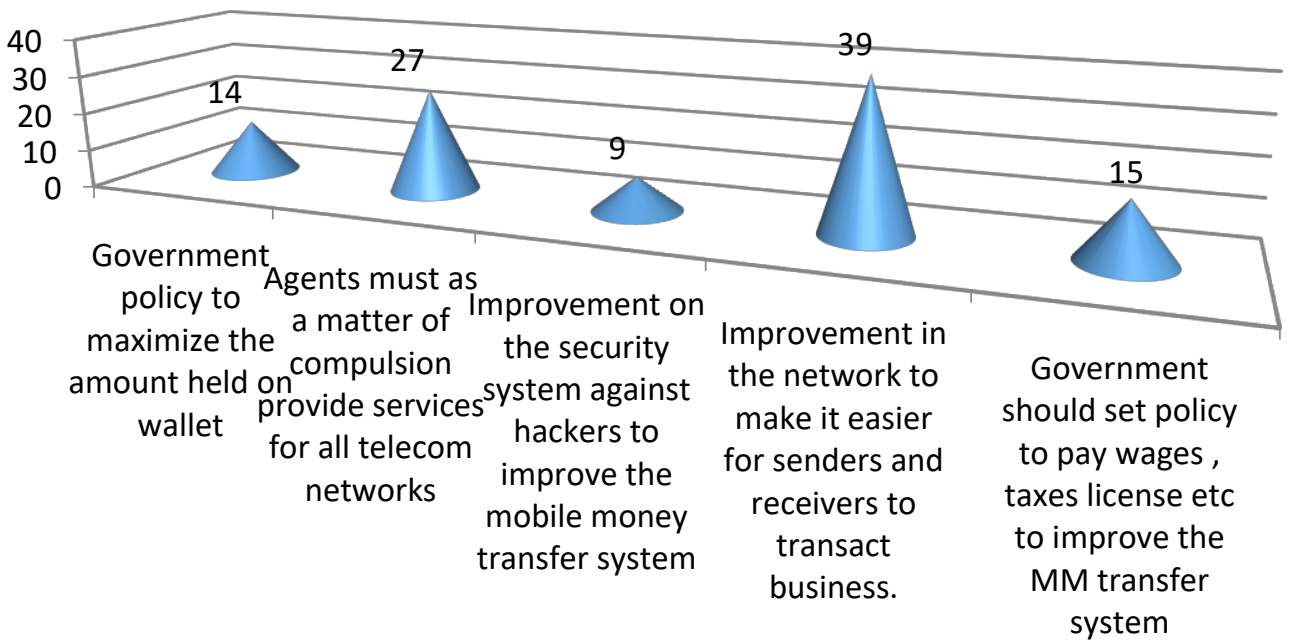

Figure 4.4 Rank Order Result on Improving the Mobile Money Transfer System Source: Field Data, 2017

The rank order results on how to improve mobile money system in Ghana are as follows:

Improvement in the workings of networks to make it easier for senders and receivers to transact business; MM agents must as a matter of compulsion provide services for all telecommunication networks; Government policies on payment of wages, taxes, licenses, etc. must seek to improve the mobile money transfer system; Government needs to design effective polices to maximise the amount of money held on customers wallet; and Improvement on the security of mobile money services against hackers. Section 4.2 analyses the data collected from the 30 bank officials of Beige Bank

\subsection{Section B: Interpretation of Data Obtained from Officials of Beige Capital}

This section analyses the data collected from the 30 bank officials of Beige Bank 1. This sectioned aimed at using the responses of the Bank's official to smoothen the rough edges of the responses received from customers of the Bank. 


\subsubsection{Mobile Money Services and Bank Account Operations}

Respondents were asked questions regarding mobile money services and bank account operations. The results are presented in Table 4.8. The findings indicate that the entire sampled respondents admitted that the bank is into MM services. In addition, $66.7 \%$ of the officials that were contacted indicated that mobile money service is a core value of the bank. However, $26.7 \%$ said MM was not a core business of the Bank. The difference in responses requires that the Bank's officials must be educated periodically about the Bank's activities and mandate.

Table 4.8 Descriptive Statistics on Mobile Money Services and Account Operations

\begin{tabular}{|c|c|c|c|c|c|c|c|}
\hline \multirow[t]{2}{*}{$\begin{array}{c}\text { Statements or Indicators } \\
\text { Bank Officials } \\
\end{array}$} & \multicolumn{2}{|c|}{ YES } & \multicolumn{2}{|c|}{ NO } & \multirow[t]{2}{*}{$\begin{array}{l}\text { Missin } \\
\text { g Value }\end{array}$} & \multirow[t]{2}{*}{$\begin{array}{l}\text { Mea } \\
\text { n }\end{array}$} & \multirow[t]{2}{*}{ SD } \\
\hline & Freq. & $\%$ & Freq. & $\%$ & & & \\
\hline $\begin{array}{l}\text { Are you into mobile money services } \\
\text { as a bank? }\end{array}$ & 30 & 100.0 & - & - & - & 1.00 & .00 \\
\hline $\begin{array}{l}\text { Is it one of your core value of } \\
\text { business operations? }\end{array}$ & 20 & 66.7 & 8 & 26.7 & 2 & 1.24 & .51 \\
\hline
\end{tabular}

Source: Field Data, 2017

\subsubsection{Effect of the Introduction of Mobile Money on the Performance of Beige Capital}

The study also examined the effect of the introduction of mobile money on the Bank's performance. In Figure 4.5, a majority of the respondents $(13.44 \%)$ reported a moderate effect, while $7.23 \%$ reported a heavy effect. Another $7.23 \%$ reported little effect, and the last $3.10 \%$ said that it had not had any effect on the bank's performance.

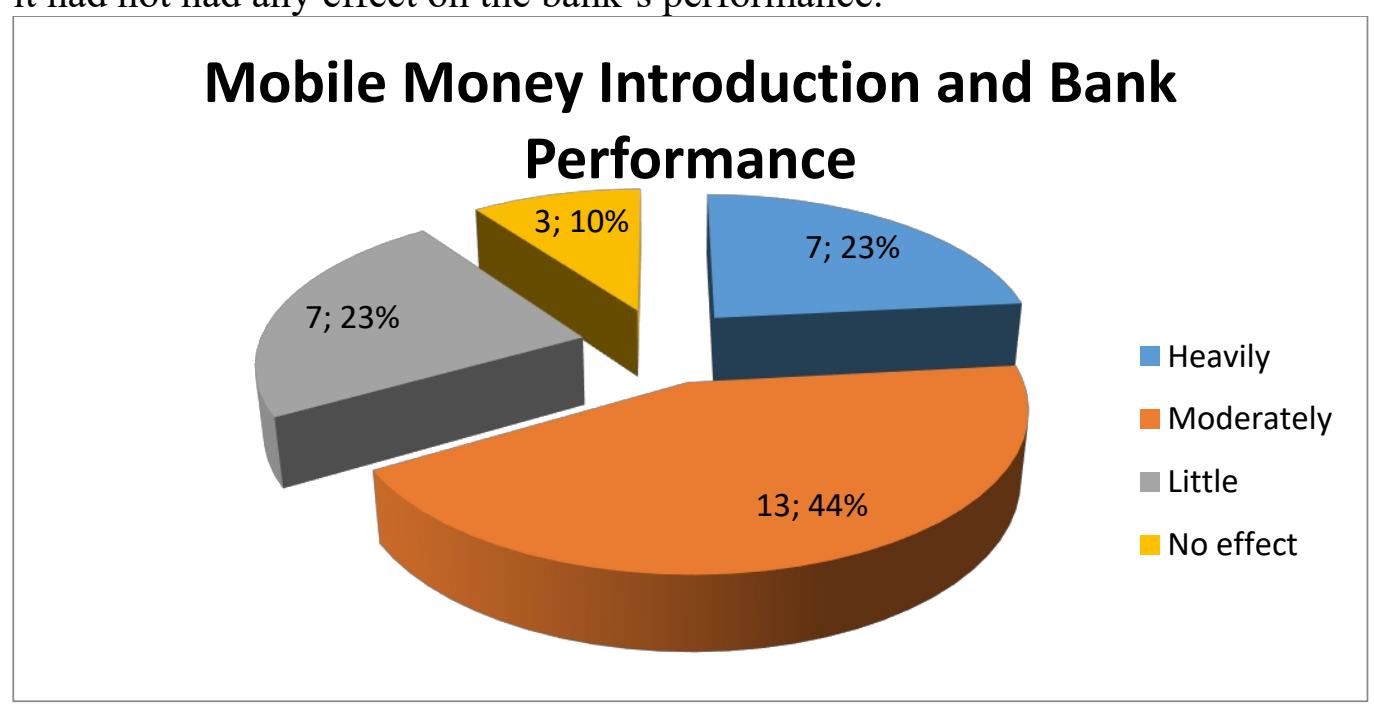

Figure 4.5 Mobile Money and Bank Performance Source: Field Data, 2017 


\subsubsection{Perception about Threats of Mobile Money Service}

This section answers the research question "What threats is Beige Capital facing with the growth of mobile money service?" the perception here is about customers dealing with MM agents instead of the Bank. The rank order result as shown in Figure 4.6 shows that, the most dominant threat that mobile money poses to the bank is reduction in savings at the banks. This is followed by mobile money agents acting as a threat to the bank's service, next is the reduction in the number of accounts creations, followed by a decrease in profits, reduction in credit creation and the lowest ranked being reduction in revenue.

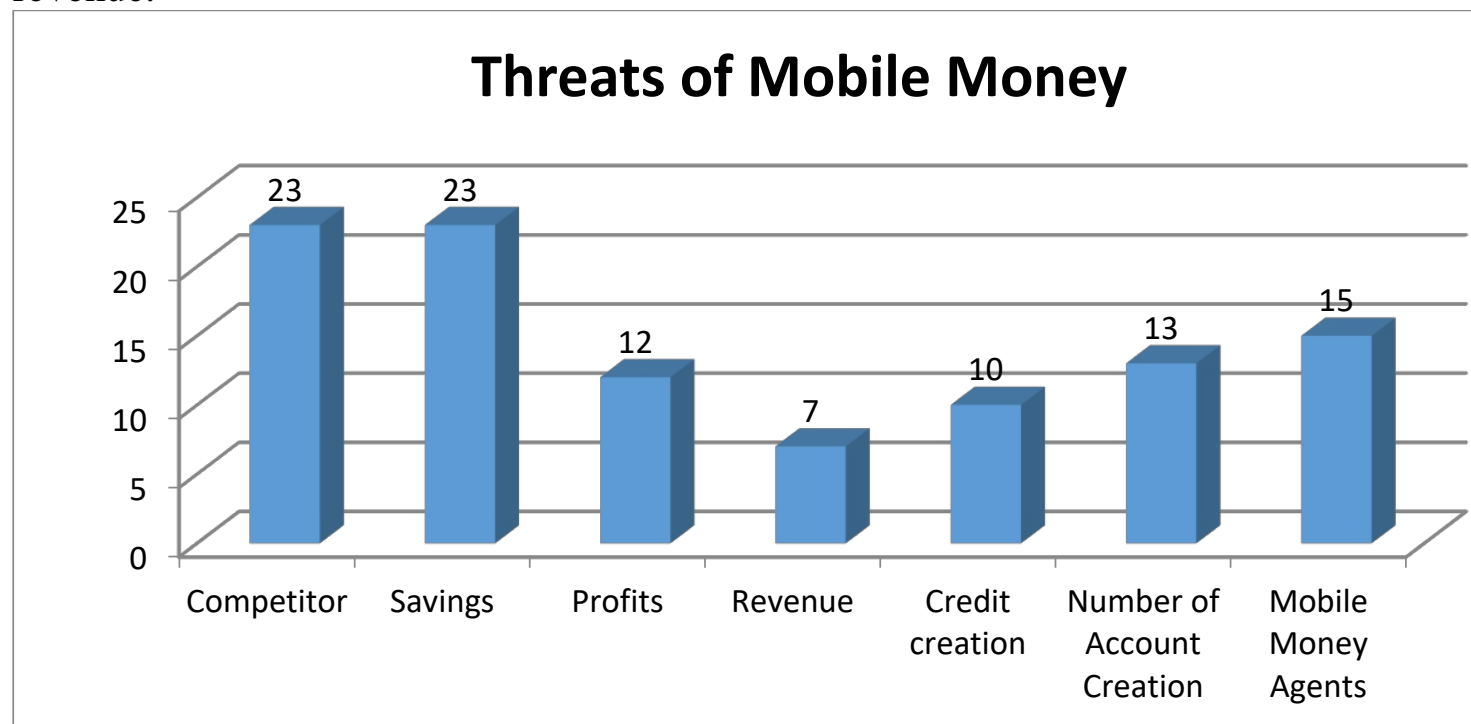

Figure 4.6 Rank Order Results on Threats of Mobile Money Service Source: Field Data, 2017

We sought the views of some senior officials of the bank to seek clarification on the threats Beige Bank faced from the growth of mobile money service and these are what they said;

"I do not see mobile money service as a threat... it is just one of the channels by which funds can be transferred. Mobile money service affects banking positively, if customers' wallets could be linked with their bank accounts, you are able to turn the person who does remittances often to the bank, that means deposits will increase, and when deposits increase it translates into increased profits for the bank. The telecom companies just provide a channel for us to do transactions and to bring the whole economy and banking closer to the people, whiles we (Beige Capital) make our money".

Another senior official also agreed that mobile money is not a threat as perceived by many, the official said, "The first thing I will mention is that, it is not really a threat but people perceive it to be so. They think that mobile 
money services have come to take over the services of banks but that is not the case."

When asked about their views on mobile money agents as a threat to Beige Capital's offering of the service, one senior official said this, "Mobile money agents are spread across the country and it is a big market, we cannot be everywhere although we are increasing our visibility. I do not see them as a threat ... what you do is you bank mobile money agents, when you bank them you register the persons wallet, whatever transaction they do go into your portfolio and the mobile money agents become mobilisers for you." The above statements support PWC (2016) and Muisyo, Alala, \& Musiega (2014), both of who advise that financial institutions should note that mobile money is an imperative route for consumer banking and has the benefit of providing massive and cheap deposits for them if they could position themselves well.

\subsubsection{Opportunities Presented by Mobile Money Service}

This section answers the research question "What opportunities is Beige Capital gaining with the growth of mobile money service?" MM services usage as a means of payment brings benefits to the user including convenience, speed, flexibility and affordability (GSMA, 2013; cited in Bank of Ghana, 2017). The results are shown as Cross selling of bank products; Commission earning; and the possibility of mobile money users eventually becoming customers of the bank. In light of the opportunities, respondents were of the view that the following measures when put in place by the bank would help harness the above opportunities: Improvement in customer relations; Introduction of mobile money apps; the Bank should have a good partnership with telecom companies; and interoperability of various mobile money service providers.

\subsubsection{The Future of Mobile Money Service in Ghana}

The study further sought from the Bank's officials the future of mobile money in Ghana. The result shown in Figure 4.7 indicates that, almost the entire sampled bank officials, representing 97\%, said mobile money service has a bright future, while only one respondent, representing $1.3 \%$ admitted a bleak future. 


\section{Future of MM in Ghana}

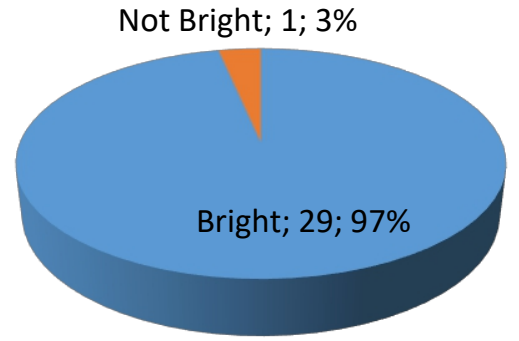

Figure 4.7 Future of Mobile Money Services with Banks in Ghana Source: Field Data, 2017

\subsection{SUMMARY, CONCLUSION, AND RECOMMENDATIONS}

\subsection{Summary}

This study examined the effects of mobile money services on customers and performance of individual banks in Ghana with specific focus on Beige Bank. The main objectives that underpinned the study are: to know the effects of MM on the saving attitude of customers of Beige Bank; to find out the effects of mobile money services on remittances of customers, to ascertain the extent of usage of MM by customers; and to identify the perceived threats, opportunities, and future of MM. Interviews and questionnaires were the primary sources of data for analysis and conclusions. From the study, it has been identified that the mobile money service has become a very popular mode for money transfers. It was also identified that although majority of Beige Bank customers had remitted monies using mobile money services through the bank, their preferred option for accessing the service was through agents, with their top two reasons being that agents are faster and closer to them than the Bank. Wari, an external remittance product and B-Cash, an internal remittance product offered by Beige Bank were identified to be struggling against mobile money in terms of patronage from customers. It was, therefore, identified from the study that mobile money exerts direct significant influence on the remittance services of Beige Bank. On the question of the effects of mobile money service on the saving attitude of Beige Bank customers, majority of respondents said they preferred to save on mobile wallet. Although Beige Bank officials did not agree that mobile money has a negative effect on savings, the response from customers showed that mobile money service exerts moderate significant effects on their saving attitude.

For the stand point of the Bank's officials, majority of them saw mobile money service as a competitor to banking and Beige Bank, with mobile money agents as the main channel of the competition. To the senior officials, mobile 
money service was not a threat, but rather another channel to increase their deposit mobilisation and remittance services, cross sell their products and increase profitability. Senior officials insisted that mobile money agents were assets to the Bank if they could properly be integrated into the banking system. On how to harness the above opportunities, officials responded that improvement in customer relations, introduction of mobile money apps, forming a good partnership with telecom companies, and the introduction of interoperability mobile networks with mobile money service are some of the way forward.

\subsection{Conclusion}

The study concludes that majority of the respondents had bank accounts; mobile money accounts: and still engaged in MM transactions. A greater number of respondents, forming $61.4 \%$ preferred accessing mobile money service through agents, whiles $38.6 \%$ preferred to access mobile money service through the Bank, because the agents services are faster, closer to clients and convenient. Respondents who used MM mobile preferred saving more on mobile money wallets. The rise of mobile money service has not negatively affected the deposit portfolio of Beige Bank Although some view mobile money service as a threat and a competitor to banking, it can be concluded from the study that once MM is integrated into the banking system, where MM agents and customers tie their wallets to their bank accounts it does not become a threat, but an opportunity to expand the scope of banking services. The study further concludes that mobile money presents many opportunities and if Beige Bank should position itself well with a mobile app, ensure better customer relations and strategic partnership with service providers, it will be able to maximize the advantages mobile money presents. However, the study is narrow in scope because it is on one bank in Ghana. Again, the sample size used is also not large enough to make a general conclusion on how the MM sector is impacting on customers of banks and performance of banks in Ghana.

\subsection{Recommendations}

It is recommended that Beige Capital should pay more attention to banking mobile money agents and in that process turn mobile money agents into mobilisers of funds for Beige Bank. By doing so, they will indirectly bank mobile money users. Also, it is recommended that Beige Bank 1 should develop a mobile phone application which has access to mobile money service so that customers can easily transfer money between their bank accounts and mobile money wallets. It is further recommended that Beige Bank should educate its customers on the benefits of saving in their bank accounts as compared to mobile money wallets. Beige Bank should explain how interests are paid on 
mobile money wallets and how customers would make more interest if they saved in their bank accounts. Beige Bank should also explain to customers the probability of their mobile money accounts being hacked into by cybercriminals. It is further recommended that Beige Bank consider giving ecash loans to mobile money agents, at reasonable interest rates as a means having accounts with them. This will attract more mobile money agents to buy e-cash from Beige Bank. In addition, it is recommended that Beige Bank together with other financial institutions should help strengthen mobile service interoperability from the mobile money service providers since this platform will ensure cross transfer of money from different service providers by the customers who use mobile money services.

Mobile money is gradually establishing itself in the financial sector as an important source of financial inclusion. However, the spate of armed robbery cases associated with mobile money activities and the death of mobile money agents in Ghana needs to be addressed urgently by the government of Ghana (Ministry of Finance and Economic Planning, Bank of Ghana, security agencies), banks, and telecom companies. The use of tables with umbrellas and containers as office spaces by mobile money agents must be critically addressed by the government, telecom companies, and banks to ensure the safety of mobile money agents and their clientele base in Ghana. It should be possible for the major stakeholders in the sector to demarcate specific areas within communities for MM agents and provide them with decent and secured office spaces with police patrol services to protect the agents and clients and the monies they transact on a daily basis. Given the recent collapse of seven indigenous Ghanaian banks between 2017 and 2018, it has become imperative for the Bank of Ghana and National Communication Authority (NCA), as a matter of urgency, to improve their supervisory roles over the mobile money sector to ensure efficient and smooth running of the sector. From the study it is recommended that further research can be conducted into other banks to ascertain the effect of mobile money services on customers and the performance of those banks in Ghana. Also, further research can be conducted into the risks associated with the use of mobile money service on customers.

\section{References}

1. Acheampong, J. (2018, July 30). 95\% rural access to phone services by 2019 - GIFEC. Daily Graphic, Page 85.

2. Agyeman, K. N. (2018). Cash payments to cease: Government encourages electronic transactions. Gaily Graphic, Thursday, May 17, 2018, page 3 .

3. Aidoo, I. (2018). Business finder., Thursday, May 10 page 15. 
4. Annerquaye-Abbey, R. (2018). Hitting the bulls-eye on interoperability and financial inclusion. Banking Survey 2018. Business and Financial Times, Monday, May21, 2018, page 2.

5. Baafi, A. A. (2018). Financial inclusion key o poverty reduction World Bank. Graphic Business. Thursday, June 28, 2018, Pg. SS06.

6. Bangens, L., \& Soderberg, B. (2008). Mobile banking-financial services for the unbanked. ICT4D, the Swedish Program for ICT in Developing Regions, SPIDER.

7. Bank of Ghana (2016). Payment systems oversight. 2016 Annual Report, www.bog.gov.gh.

8. Bank of Ghana (2016). September 2016 payment system statistics. www.bog.gov.gh.

9. Bank of Ghana (2017). Impact of mobile money on the payment system in Ghana: An econometric analysis. Payment Systems Department. www.bog.gov.gh.

10. Branson, H. W. (1989). Macroeconomic theory and policy. $3^{\text {rd }}$ ed., New York: Harper \& Row

11. Bruce, E. (2018). Over $7 m$ Ghanaians remain unbanked: Financial inclusion strategy in the offing. Graphic Business. Thursday, June 28, 2018, Pg. SS03.

12. Chogi, B. (2006). The impact of mobile phone technologies on small and medium enterprises. A Paper Presented to Communication Policy Research South on National Regional Innovation Systems, Nairobi. 120.

13. Consultative Group to Assist the Poor (CGAP; 2015a). Financial inclusion insights: mobile money momentum in four African countries. www.cgap.org.

14. Consultative Group to Assist the Poor (CGAP, 2015). Ghana summary report national survey. Financial Inclusion Insights, Applied Research for Digital Financial Inclusion, www.finclusion.org.

15. Creswell, J.W. (2009). Research design: Qualitative, quantitative and mixed methods approaches. 3rd ed., California: Sage Publications.

16. Demirgüç-Kunt, A., Beck, T., \& Honohan, P. (2008). Finance for all?: Policies and pitfalls in expanding access. World Bank

17. Demirgüç-Kunt, A., \& Klapper, L. F. (2012). Measuring financial inclusion: The global findex database. World Bank Policy Research Working Paper, (6025).

18. Demirguc-Kunt, A., Klapper, L., Singer, D., \& Oudheusden, V. P. (2015). The Global Findex Database 2014: Measuring financial inclusion around the world. Policy Research Working Paper 7255, World Bank Group. 
19. Demirguc-Kunt, A., Klapper, L., Singer, D., Asar, S., \& Hess, J. (2018). The Global Findex Database 2017: Measuring financial inclusion and the Fintech revolution. Washington, DC: International Bank for Reconstruction and Development/The World Bank.

20. Bank of Ghana (2015). BoG issues guidelines to regulate mobile financial services. Www.bog.gov.gh.

21. GSMA (2015). 2015 State of the industry report: Mobile money. www.gsma.com.

22. GSMA (2016). 2016 global mobile trends. WWW.gsmaintelligence.com.

23. Haggins, D., Kendall, J., \& Lyon, B. (2012). Mobile money usage patterns of Kenyan small and medium enterprises innovations, 7(2), 67-81.

24. Jack, W., \& Suri, T. (2011). Mobile money: The economics of M-PESA. National Bureau of Economic Research, No. w16721.

25. Jensen, R. (2007). The digital provide: Information (technology), market performance, and welfare in the South Indian fisheries sector. The Quarterly Journal Of Economics, 122(3), 879-924.

26. Kodan, S. A., \& Chhikara, S. K. (2013). A theoretical and quantitative analysis of financial inclusion and economic growth. Management and Labour Studies, 38, 1\&2 (2013): 103-133

27. Kwawukume, V., \& Syme, S. (2018). Veep launches mobile money interoperability service. Allows direct transfer of funds from Ghana, Tanzania and Kenya. Daily Graphic, Friday, May 11, 2018, page 38.

28. Kyeremeh, G. (2018). Business finder. Thursday, May 10, 2018, page 8.

29. Lartey, S. S. (2016). Ghana's microfinance's biggest challenges: any hope for the future? Modern Ghana.

30. Llewellyn-Jones, L. (2016). Mobile Money: Part of the African Financial Inclusion Solution? Economic Affairs, 36(2), 212-216.

31. Mbogo, M. (2010). The impact of mobile payments on the success and growth of micro-business: The case of M-Pesa in Kenya. Journal of Language, Technology \& Entrepreneurship in Africa, 2(1), 182-203.

32. Mishkin, S. F. (2015). The economics of money, banking and financial markets. $11^{\text {th }}$ ed., New Jersey: Pearson.

33. Muisyo, J. M., Alala, O., \& Musiega, D. (2014). The Effects of Mobile Money Services on the Performance of the Banking Institutions: A Case of Kakamega Town. Transactions, 354(16,700,000), 4-600.

34. National Communications Authority (NCA, 2016). 2016 Second Quarter Statistical Bulletin on Communications in Ghana. Vol. 1, Issue 2, The Research and Development Division, www.nca.org.gh. 
35. Ngaruiya, B., Bosire, M., \& Kamau, S. (2014). Effect of Mobile Money Transactions on Financial Performance of Small and Medium Enterprises in Nakuru Central Business District. Research Journal of Finance and Accounting, 5 (12): 53, 58.

36. Ong-A-Kwie-Jurgens, N. (2016). Identifying constraints to financial inclusion and their impact on GDP and inequality: A case of Suriname. Centrale Bank Van Suriname

37. Polit, D. H., \& Hungler, P. B. 1999. Nursing research. Principles and methods. $6^{\text {th }}$ ed., Philadelphia, USA: Lippincott Williams \& Wilkins.

38. Price Water House Coopers (PWC, 2016). 2016 Ghana banking survey: How to win in an era of mobile money. www.pwc.com/gh.

39. Sidik, Z. N., Achsani, N. A., \& Pasaribu, S. H. (2018). Financial inclusion and demand for money: A dynamic panel data approach. Signifikan: Journal Ilmu Ekonomi. Vol. 7 (2): 137 - 148. doi: http//dx.doi.org/10.15408/ sjie.v7i2.6838.

40. World Bank Group (2015). Universal financial access by 2020. ufa.worldbank.org.

41. World Bank Group (2018). The global financial development report: Bankers without borders. Global Financial Development 2017/2018, NW, Washington. 